\title{
Supporting Information \\ Reversible Fluorescent Probe for Selective Detection and Cell Imaging of Oxidative Stress Indicator Bisulfite
}

Yajiao Zhang, ${ }^{\dagger, *, \perp}$ Lingmei Guan, ${ }^{\|, \perp}$ Huan Yu, ${ }^{\dagger, \downarrow}$ Yehan Yan, ${ }^{\dagger, \downarrow}$ Libo Du, ${ }^{\|}$Yang Liu, ${ }^{\|}$Mingtai Sun,,${ }^{+,, \downarrow}$ Dejian Huang, ${ }^{\S}$ Suhua Wang*, ${ }^{*}, \ldots$

†Institute of Intelligent Machines, Chinese Academy of Sciences, Hefei, Anhui 230031,China

Department of Materials Science and Engineering, University of Science and Technology of China, Hefei, Anhui 230026, China

${ }^{\S}$ Food Science and Technology Programme, Department of Chemistry, National University of Singapore, 3 Science Drive 3, Singapore 117543, Republic of Singapore

"State Key Laboratory for Structural Chemistry of Unstable and Stable Species, Center for Molecular Sciences, Institute of Chemistry, Chinese Academy of Sciences, Beijing 100190, China

\section{Table of Contents}

Experimental Section

Figure S1. Determination of the fluorescence quantum yield of HBT-Cy using Rhodamine B in ethyl alcohol solution as standard.

Figure S2. ${ }^{1} \mathrm{H}$ NMR spectrum of probe HBT-Cy in DMSO- $\mathrm{d}_{6}$

Figure S3. ESI-MS spectrum of HBT-Cy.

Figure S4. ESI-MS spectrum of HBT-CHO.

Figure S5. UV-vis and fluorescence spectra of $\mathrm{Cy}-\mathrm{OH}(50 \mu \mathrm{M})$ upon addition of $50 \mu \mathrm{M}$ of $\mathrm{HSO}_{3}{ }^{-}$, then following treated with $\mathrm{H}_{2} \mathrm{O}_{2}(50 \mu \mathrm{M})$ and TBHP $(50 \mu \mathrm{M})$ at $37^{\circ} \mathrm{C}$ for $1 \mathrm{~h}$, respectively.

Figure S6. ESI-MS spectrum of $\mathrm{Cy}-\mathrm{OH}$.

Figure S7. ESI-MS spectra of the reaction solution of $\mathrm{Cy}-\mathrm{OH}$ plus $\mathrm{HSO}_{3}{ }^{-}$.

Figure S8. ESI-MS spectra of the reaction solution of Cy-OH plus $\mathrm{HSO}_{3}{ }^{-}, \mathrm{H}_{2} \mathrm{O}_{2}$ in order.

Figure S9. Determination of the fluorescence quantum yield of $\mathrm{Cy}-\mathrm{OH}$ based on Rhodamine $\mathrm{B}$ as standard.

Figure S10. $\mathrm{pH}$ dependence of fluorescence intensity of probe HBT-Cy $(10 \mu \mathrm{M})$ in the absence/presence of $\mathrm{HSO}_{3}{ }^{-}$.

Figure S11. Time courses of the responses between HBT-Cy $(10 \mu \mathrm{M})$ with $\mathrm{HSO}_{3}{ }^{-}$at different concentrations.

Figure S12. Fluorescence spectra of HBT-Cy $\left(10 \mu \mathrm{M}, \lambda_{\mathrm{ex}}=520 \mathrm{~nm}\right)$ in the presence of different concentrations of $\mathrm{HSO}_{3}{ }^{-}$.

Figure S13. Ratiometric calibration curve of $\mathrm{F}_{450} / \mathrm{F}_{590}$ as a function of $\mathrm{HSO}_{3}{ }^{-}$concentration.

Figure S14. ESI-MS spectra of the reaction solution of HBT-Cy plus $\mathrm{HSO}_{3}{ }^{-}$.

Figure S15. ${ }^{1} \mathrm{H}$ NMR spectrum of the fluorescence product HBT-CyO in DMSO $/ \mathrm{D}_{2} \mathrm{O}=8: 1(\mathrm{v} / \mathrm{v})$.

Figure S16. Selectivity and interference of HBT-Cy towards $\mathrm{HSO}_{3}{ }^{-}$in the presence of other common species in PBS 7.0 solution.

Figure S17. ${ }^{1} \mathrm{H}$ NMR titration spectra of HBT-Cy in DMSO- $\mathrm{d}_{6}$ upon addition of $\mathrm{HSO}_{3}{ }^{-}$in $\mathrm{D}_{2} \mathrm{O}$ and subsequent addition of $\mathrm{H}_{2} \mathrm{O}_{2}$ $\left(\mathrm{D}_{2} \mathrm{O}\right)$.

Figure S18. ESI-MS spectra of the reaction solution of HBT-Cy plus $\mathrm{HSO}_{3}{ }^{-}, \mathrm{H}_{2} \mathrm{O}_{2}$ in order.

Figure S19. ${ }^{1} \mathrm{H}$ NMR spectrum of the restored probe HBT-Cy in $\mathrm{DMSO} / \mathrm{D}_{2} \mathrm{O}=8: 1(\mathrm{v} / \mathrm{v})$.

Figure S20. Reaction of $\mathrm{SO}_{2}$ donor in the presence of Cys.

Figure S21. ESI-MS spectra of $\mathrm{SO}_{2}$ donor.

Figure S22. Confocal imaging of living MCF-7 cells incubated with different concentrations of $\mathrm{NaHSO}_{3}$ in the blue channel, bright field, red channel and overlay field (left to right).

Figure S23. Cytotoxicity assay of probe HBT-Cy at different concentrations for MCF-7 cells after $24 \mathrm{~h}$.

Figure S24. Ratiometric fluorescence spectra of HBT-Cy $(20 \mu \mathrm{M})$ upon addition of $\mathrm{SO}_{2}$ gas $(0-500 \mathrm{ppm})$.

Figure S25. Plot of the fluorescence intensity ratio (F450/F590) for HBT-Cy (20 $\mu \mathrm{M})$ vs the concentration of SO2 gas.

Table S1. Recovery test of $\mathrm{HSO}_{3}{ }^{-}$spiked in tap water, lake water and rain water.

Reference 


\section{Experimental Section}

Synthetic procedures

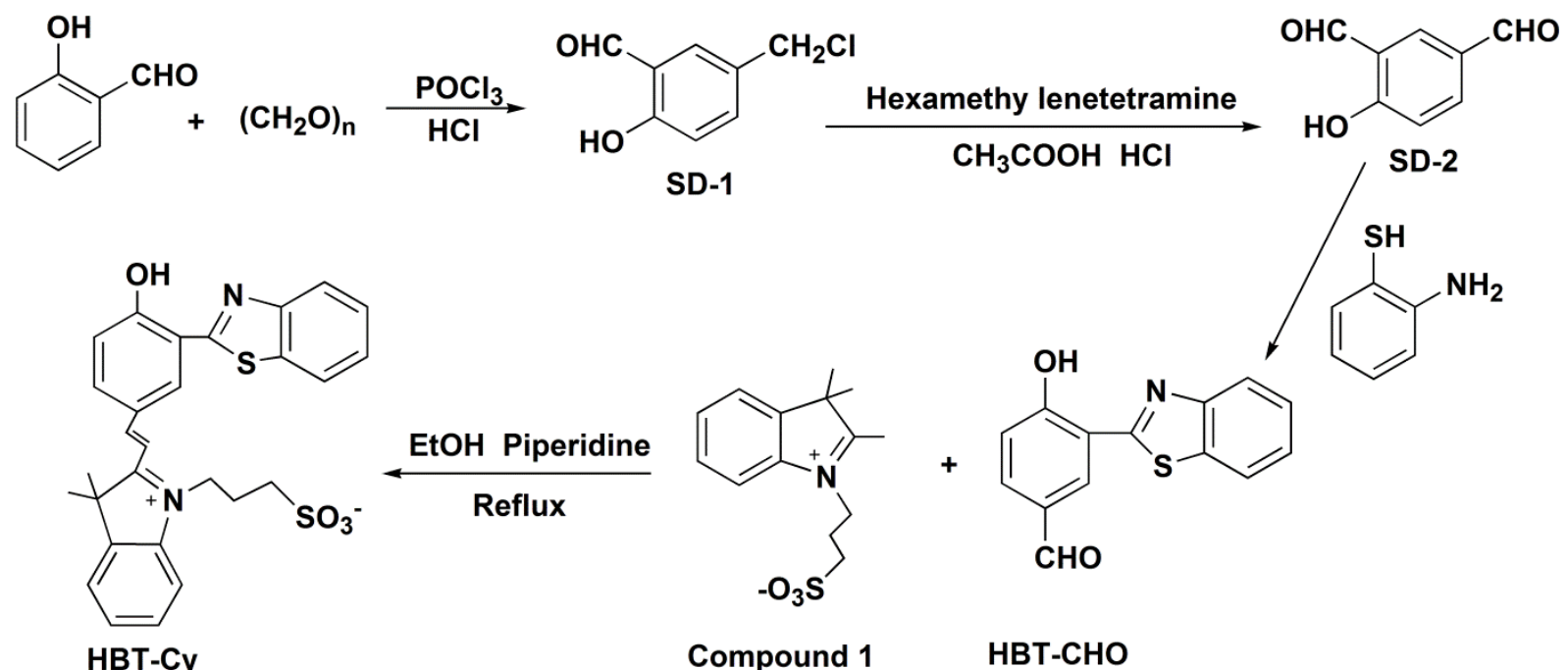

Scheme S1. Design and synthetic procedure of the novel ratiometric fluorescent probe HBT-Cy.

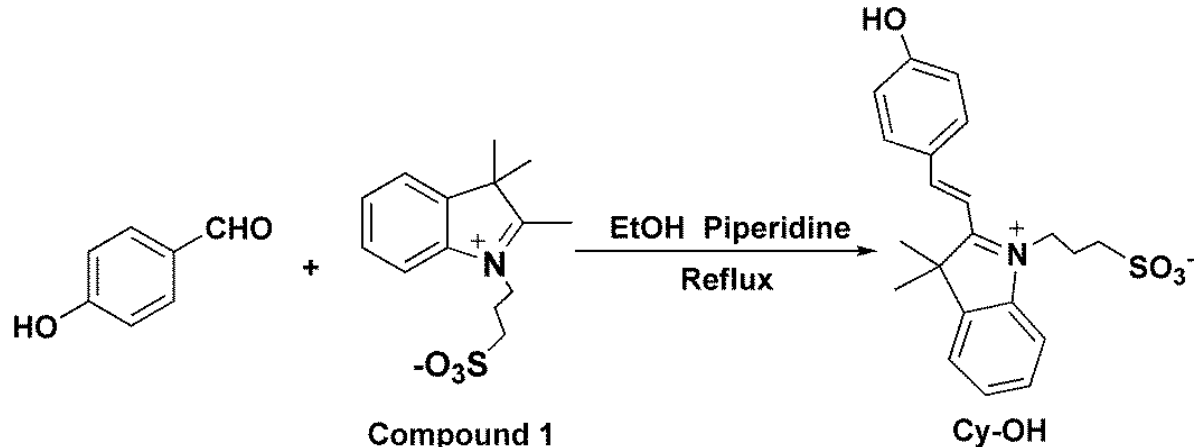

Scheme S2. Design and synthesis of Cy-OH for comparison with HBT-Cy.

Synthesis of 2,3,3-Trimethyl-1-(3-sulfonatepropyl)-3H-indolium (compound $\mathbf{1})^{\mathrm{S} 1}$. 1,3-propane sultone (422 mg, $3.45 \mathrm{mmol}$ ) was slowly added to a solution of 2,3,3-trimethylindolenine (500 mg, $3.14 \mathrm{mmol})$ in 1,2-dichlorobenzene (3 mL). The mixing solution was reacted at a temperature of $120{ }^{\circ} \mathrm{C}$ for $18 \mathrm{~h}$. At last, the solvent was removed under vacuum and the purple product was washed with diethyl ether and dried in vacuum.

Synthesis of 5-Chloromethyl-2-hydroxy-benzaldehyde (SD-1). Salicylaldehyde (1.17 g, $5 \mathrm{~mL})$ and paraformaldehyde (2.35 g) was added to a three-necked flask with $20 \mathrm{~mL}$ of concentrated $\mathrm{HCl}$. The mixed solution started to stir, and $1.5 \mathrm{~mL}$ of $\mathrm{POCl}_{3}$ was gradually added dropwise within $1 \mathrm{~h}$. The mixing reaction was reacted at room temperature for $18 \mathrm{~h}$. the crude precipitate was got by filtration and washed with $3 \% \mathrm{NaHCO}_{3}$ aqueous solution and distilled water. In the end, the crude product was dried under vacuum and recrystallized by petroleum ether, and then we obtained a white solid produce SD-1 $(1.03 \mathrm{~g}, 63 \%)^{\mathrm{S} 2}$.

Synthesis of 4-Hydroxybenzene-1,3-dicarbaldehyde (SD-2). 5-Chloromethyl-2-hydroxy-benzaldehyde (SD-1) (2.13 g, 12.5 $\mathrm{mmol})$ was treated with hexamethylenetetramine $(2.27 \mathrm{~g}, 16.2 \mathrm{mmol})$ in $13 \mathrm{~mL} 50 \%$ acetic acid aqueous solution under stirring, the reaction mixture was refluxed for $1 \mathrm{~h}$, and $6 \mathrm{~mL}$ of concentrated hydrochloric acid was then added. Finally, the yellow solution was refluxed for 5 more minutes and cooled in an ice bath to obtain SD-2 as light yellow needle crystals (1.1 g, $60 \%)$.
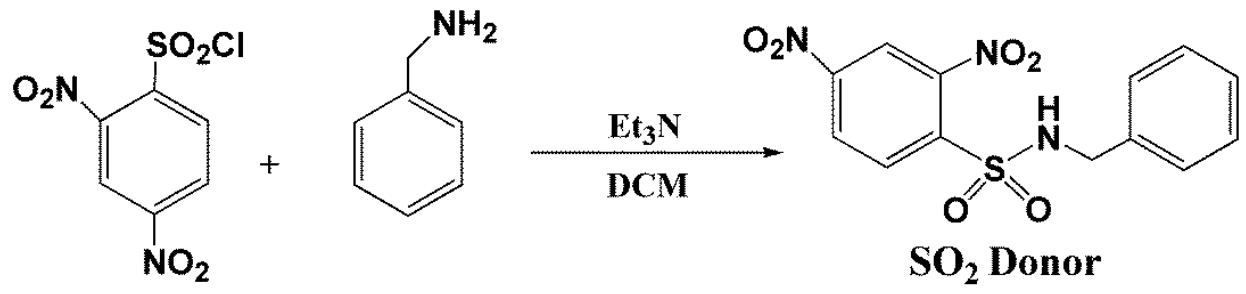

Scheme S3. Synthesis of $\mathrm{SO}_{2}$ donor.

Synthesis of N-benzyl-2, 4-dinitrobenzensulfonamide ( $\mathrm{SO}_{2}$ donor). According to the method in the literature ${ }^{\mathrm{S} 4}$, 2 , 
4-dinitrobenzensulfonyl chloride $(0.198 \mathrm{~g}, 0.75 \mathrm{mmol})$ in $6 \mathrm{~mL}$ dry $\mathrm{DCM}$ at $0{ }^{\circ} \mathrm{C}$ was added to a solution of benzylamine $(0.159 \mathrm{~g}$, $1.5 \mathrm{mmol})$ with trimethylamine $(0.321 \mathrm{~g}, 3 \mathrm{mmol})$ and $9 \mathrm{~mL} \mathrm{DCM}$, the mixture was stirred and reacted for $3 \mathrm{~h}$ at room temperature, then $15 \mathrm{~mL}$ of water was added to the solution to stop the reaction. Extracted by DCM, and the organic layer was dried by anhydrous $\mathrm{Na}_{2} \mathrm{SO}_{4}$. The solvent was removed under vacuum to get the crude product and the pure light yellow product was collected by chromatography using DCM as eluent. ESI-MS m/z calcd for $\mathrm{C}_{13} \mathrm{H}_{11} \mathrm{~N}_{3} \mathrm{O}_{6} \mathrm{~S}[\mathrm{M}+\mathrm{H}]^{+}, 337.04$, found 338.34 .

\section{Materials and Methods}

All reagents and solvents were of analytical grade purchased from Sinopharm Chemical Reagent Co. Ltd or Aladdin Reagent Co. Ltd and used without further purification unless stated otherwise. All solutions were prepared using ultrapure water $(18.2 \mathrm{M} \Omega \bullet \mathrm{cm})$ produced by a Millipore purification system. All the experiments were carried out at room temperature unless noted otherwise. Fluorescence measurement was recorded on a Perkin-Elmer LS-55 luminescence spectrometer with a $500 \mathrm{~nm} / \mathrm{min}$ scan rate. UV-Vis absorption was recorded on a Shimadzu UV-2550 spectrometer. Photographs were taken with a canon 350D digital camera. $\mathrm{pH}$ values are determined by PHS-3C $\mathrm{pH}$ meter. ${ }^{1} \mathrm{H} \mathrm{NMR}$ spectra were measured using a Varian Mercury-400 NMR spectrometer, and mass spectra were performed on a Thermo Proteome X-LTQ MS mass spectrometer in ES positive or negative mode. Silica gel-60 (230-400 mesh) was used as the solid phases for column chromatography. Confocal images were scanned by Laser Confocal Microscopy (OBSERVER Z1, ZEISS) and a $60 \times$ oil-immersion objective lens. MCF-7 (Michigan Cancer Foundation -7) was purchased from American Type Culture Collection (ATCC). They were cultured in the DMEM with 10\% fetal bovine serum (FBS) at $37^{\circ} \mathrm{C}$ in humidity incubator containing $5 \% \mathrm{CO}_{2}$.

\section{Selectivity and Interference Measurements}

For the selectivity experiments, other species $\left(\mathrm{HSO}_{3}^{-}, \mathrm{F}^{-}, \mathrm{Cl}^{-}, \mathrm{Br}^{-}, \mathrm{I}^{-}, \mathrm{CO}_{3}{ }^{2-}, \mathrm{AcO}^{-}, \mathrm{NO}_{2}^{-}, \mathrm{S}_{2} \mathrm{O}_{8}{ }^{2-}, \mathrm{S}_{2} \mathrm{O}_{3}{ }^{2-}, \mathrm{SCN}^{-}, \mathrm{HPO}_{4}{ }^{2-}, \mathrm{HS}^{-}, \mathrm{CN}^{-}, \mathrm{Vc}\right.$, $\mathrm{Cys}, \mathrm{GSH}$, and BSA) were added into the probe solutions in PBS 7.0, respectively. The concentrations of $\mathrm{HSO}_{3}^{-}$and other substances were $50 \mu \mathrm{M}$ and $500 \mu \mathrm{M}$, respectively. For the interference experiments, $\mathrm{HSO}_{3}^{-}(50 \mu \mathrm{M})$ coexisted with other interference species $(500 \mu \mathrm{M})$ were prepared and then mixed with the probe solution in PBS 7.0. After 15 minutes, the resulting solutions were determined by the fluorescence spectra in the range from $540 \mathrm{~nm}$ to $750 \mathrm{~nm}$ using a $520 \mathrm{~nm}$ excitation wavelength.

\section{Reversibility Measurements}

To verify the validity of the reversibility, we chose the one adding $50 \mu \mathrm{M}$ of $\mathrm{HSO}_{3}{ }^{-}$to continue the reversibility measurement. Different species of reactive oxygen species $\left(\mathrm{NaClO}, \mathrm{KO}_{2}, \mathrm{H}_{2} \mathrm{O}_{2}\right.$, TBHP, $\cdot \mathrm{O}^{\mathrm{t}} \mathrm{Bu},{ }^{1} \mathrm{O}_{2}$, and $\left.\mathrm{HO} \cdot 50 \mu \mathrm{M}\right)$ were injected into the HBT-CyO solutions, respectively. Blank group was prepared by adding pure water with the same volume to the probe solution. The mixtures were treated with water bath at $37{ }^{\circ} \mathrm{C}$ for 60 minutes, and then the fluorescence spectra were recorded in the range from $410 \mathrm{~nm}$ to $750 \mathrm{~nm}$ using a $390 \mathrm{~nm}$ excitation wavelength.

\section{Fluorescence Quantum Yield Measurement}

Fluorescence quantum yield of HBT-Cy was calculated using the following equation.

$$
\Phi_{\mathrm{F} \mathrm{sample}}=\Phi_{\mathrm{F} \text { standard }} \cdot \frac{\mathrm{Abs}_{\text {standard }}}{\mathrm{Abs}_{\text {sample }}} \cdot \frac{\sum \mathrm{F}_{\text {sample }}}{\sum \mathrm{F}_{\text {standard }}} \cdot \frac{\eta_{\text {sample }}^{2}}{\eta_{\text {standard }}^{2}}
$$

Where $\Phi_{\mathrm{F}}$ stands for fluorescence quantum yields; Abs and $\Sigma \mathrm{F}$ denote the absorbance at the excitation wavelength and the measured integrated fluorescence intensity, and $\eta$ is the refractive index of the solvent used. Rhodamine B in ethyl alcohol solution $\left(\Phi_{\mathrm{F}}=0.71\right)^{\mathrm{S} 3}$ was selected as standards for probe $\mathrm{Cy}-\mathrm{OH}$ and HBT-Cy.

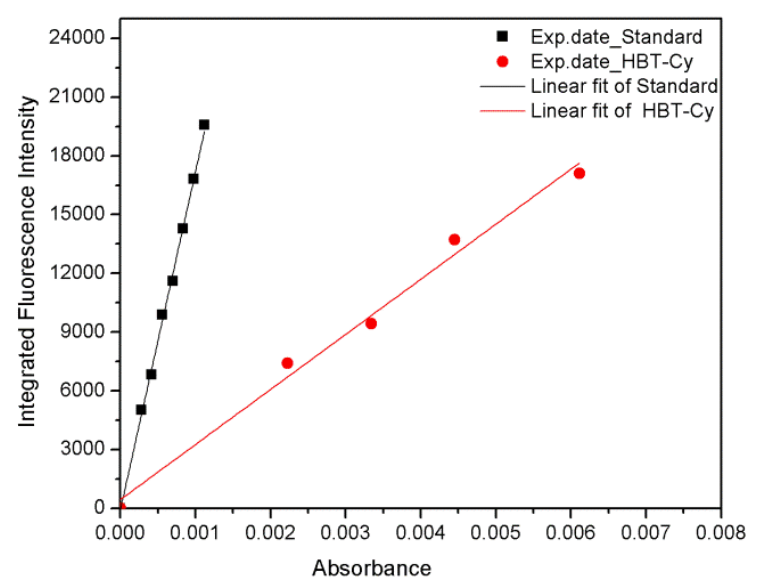

Figure S1. Determination of the fluorescence quantum yield of HBT-Cy using Rhodamine B in ethyl alcohol solution as standard. 


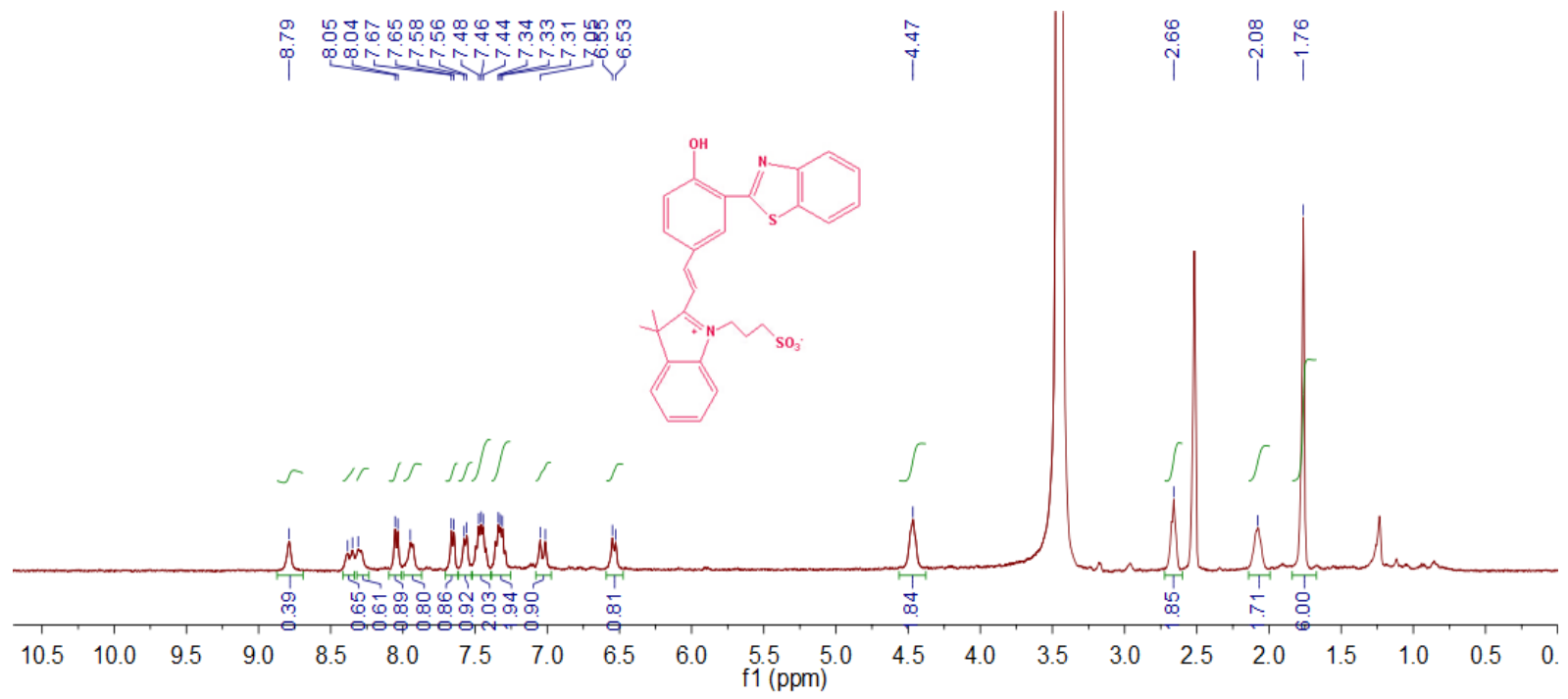

Figure S2. ${ }^{1} \mathrm{H}$ NMR spectrum of probe HBT-Cy in DMSO- $\mathrm{d}_{6} \cdot{ }^{1} \mathrm{H}$ NMR $\left(400 \mathrm{MHz}, \mathrm{DMSO}-\mathrm{d}_{6}\right) \delta 8.79(\mathrm{~s}, 1 \mathrm{H}), 8.37(\mathrm{~d}, J=13.6 \mathrm{~Hz}$, $1 \mathrm{H}), 8.31(\mathrm{~s}, 1 \mathrm{H}), 8.04(\mathrm{~d}, J=7.6 \mathrm{~Hz}, 1 \mathrm{H}), 7.95(\mathrm{~s}, 1 \mathrm{H}), 7.66(\mathrm{~d}, J=7.4 \mathrm{~Hz}, 1 \mathrm{H}), 7.57(\mathrm{~d}, J=7.4 \mathrm{~Hz}, 1 \mathrm{H}), 7.52-7.39(\mathrm{~m}, 2 \mathrm{H})$, $7.39-7.25(\mathrm{~m}, 2 \mathrm{H}), 7.03(\mathrm{~d}, J=14.2 \mathrm{~Hz}, 1 \mathrm{H}), 6.54(\mathrm{~d}, J=9.0 \mathrm{~Hz}, 1 \mathrm{H}), 4.47(\mathrm{~s}, 2 \mathrm{H}), 2.66(\mathrm{~s}, 2 \mathrm{H}), 2.08(\mathrm{~s}, 2 \mathrm{H}), 1.76(\mathrm{~s}, 6 \mathrm{H})$.

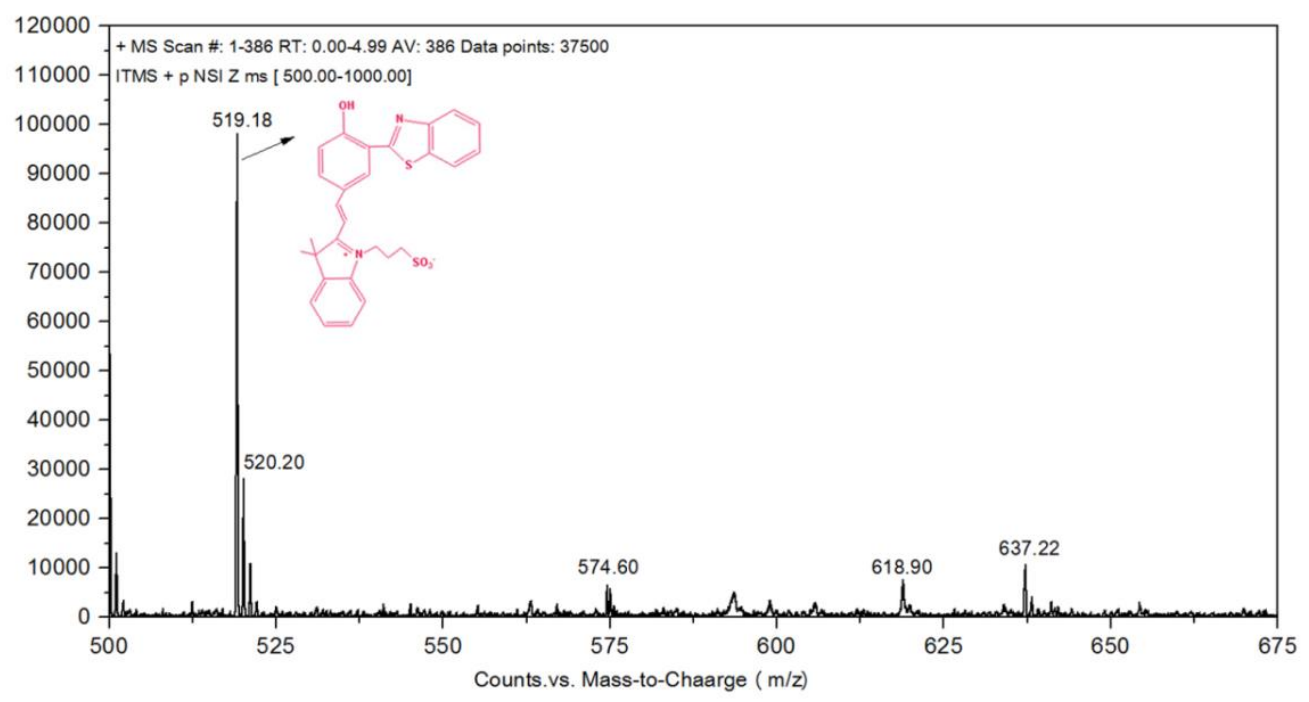

Figure S3. ESI-MS spectrum of the probe HBT-Cy. 


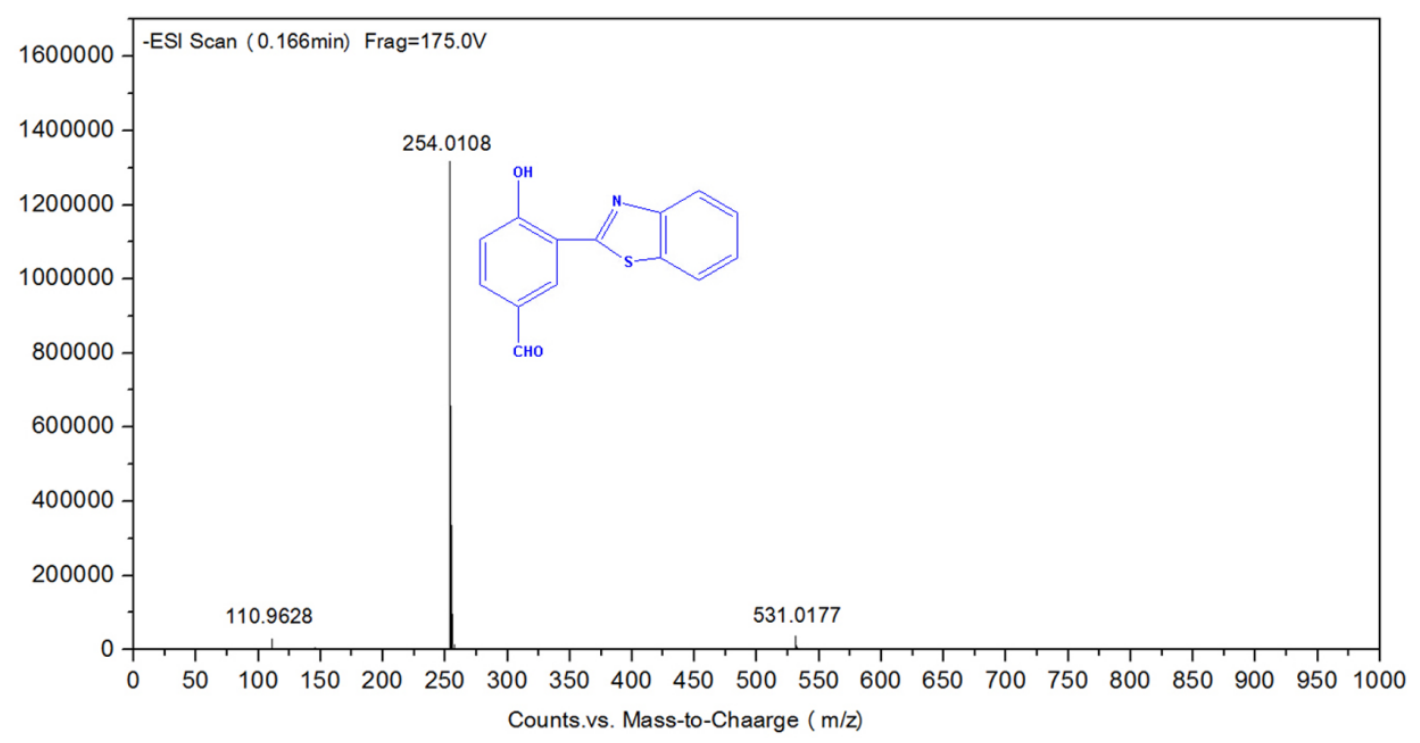

Figure S4. ESI-MS spectrum of HBT-CHO.
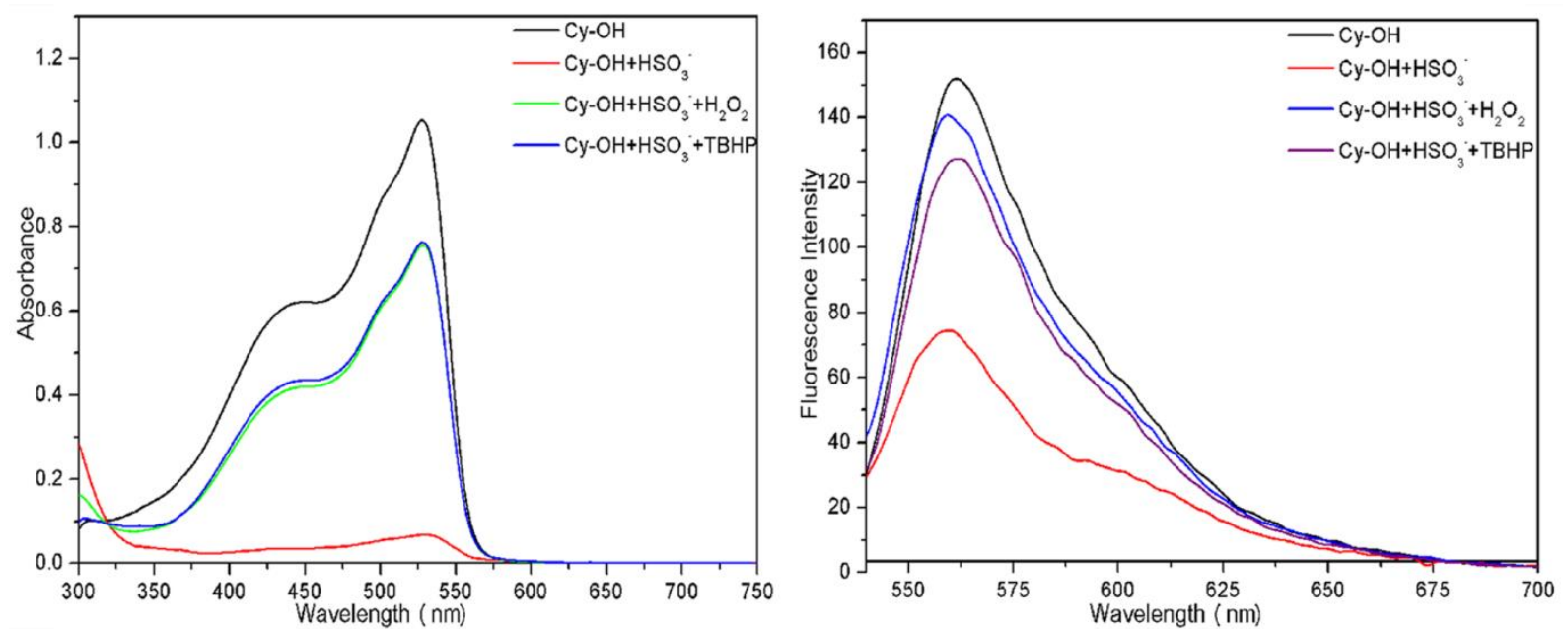

Figure S5. UV-vis and fluorescence spectra of $\mathrm{Cy}-\mathrm{OH}(50 \mu \mathrm{M})$ upon addition of $50 \mu \mathrm{M}$ of $\mathrm{HSO}_{3}{ }^{-}$, then following treated with $\mathrm{H}_{2} \mathrm{O}_{2}$ $(50 \mu \mathrm{M})$ and TBHP $(50 \mu \mathrm{M})$ at $37^{\circ} \mathrm{C}$ for $1 \mathrm{~h}$, respectively. 


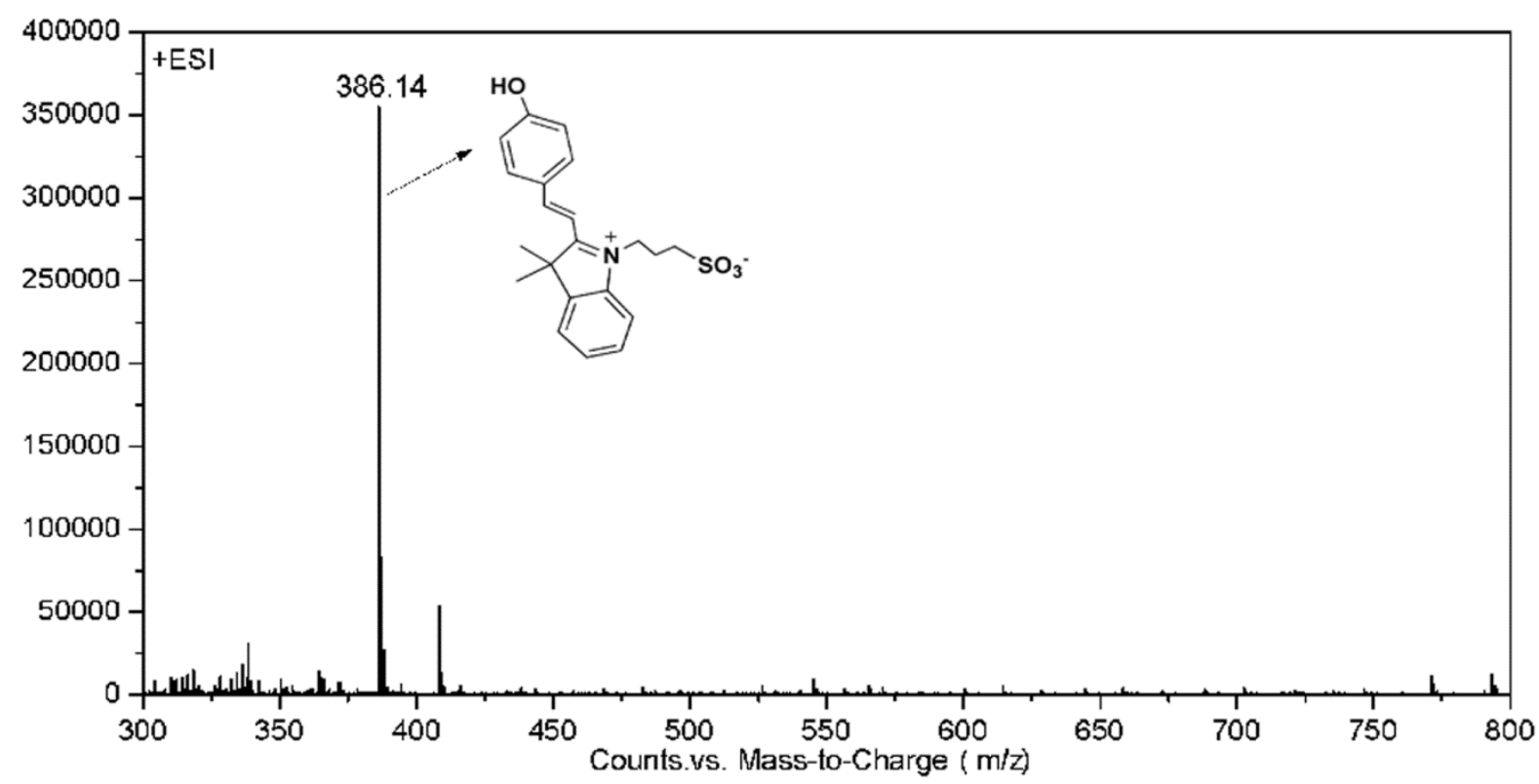

Figure S6. ESI-MS spectrum of $\mathrm{Cy}-\mathrm{OH}$.

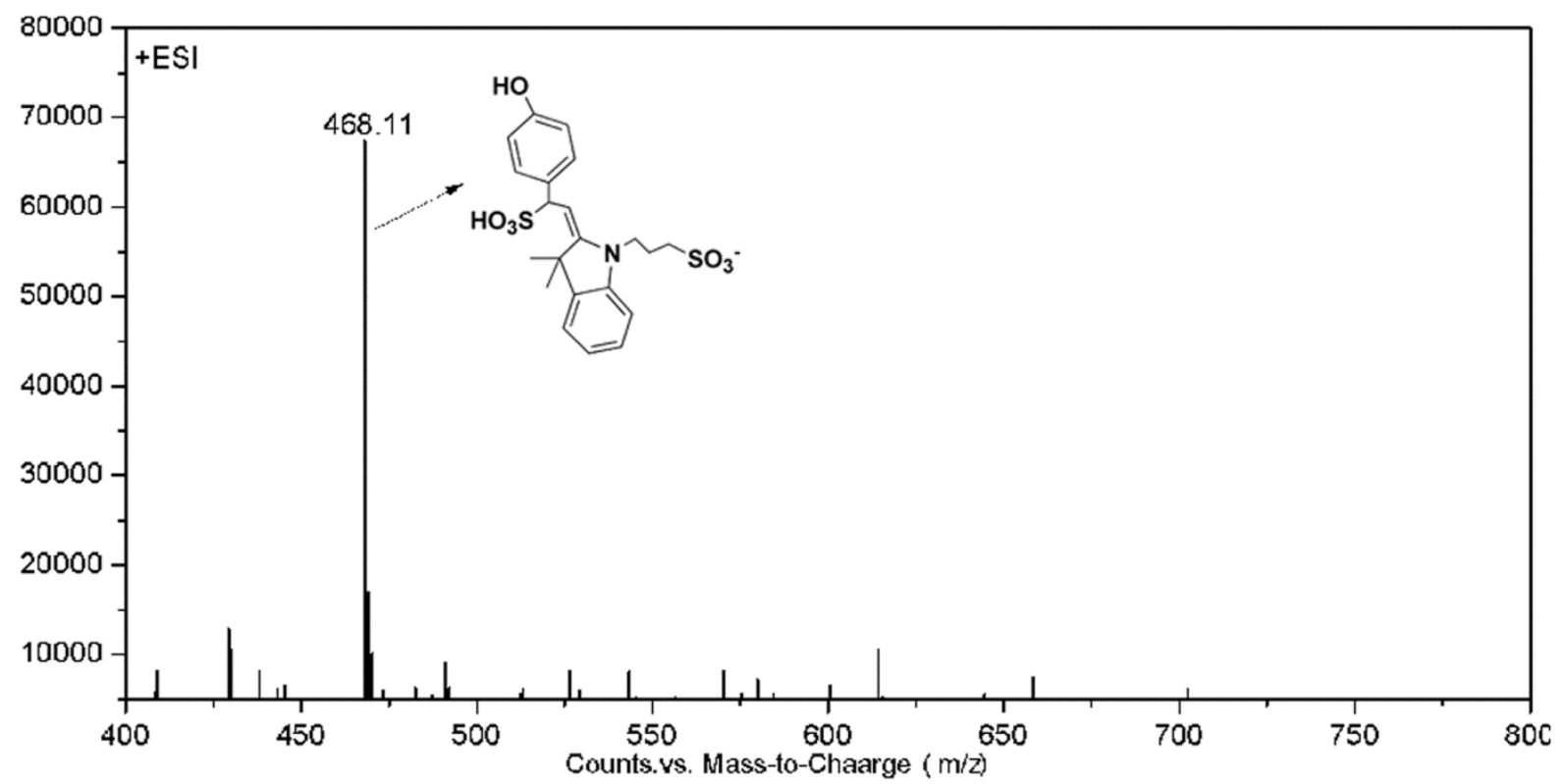

Figure S7. ESI-MS spectra of the reaction solution of $\mathrm{Cy}-\mathrm{OH}$ plus $\mathrm{HSO}_{3}{ }^{-}$. 


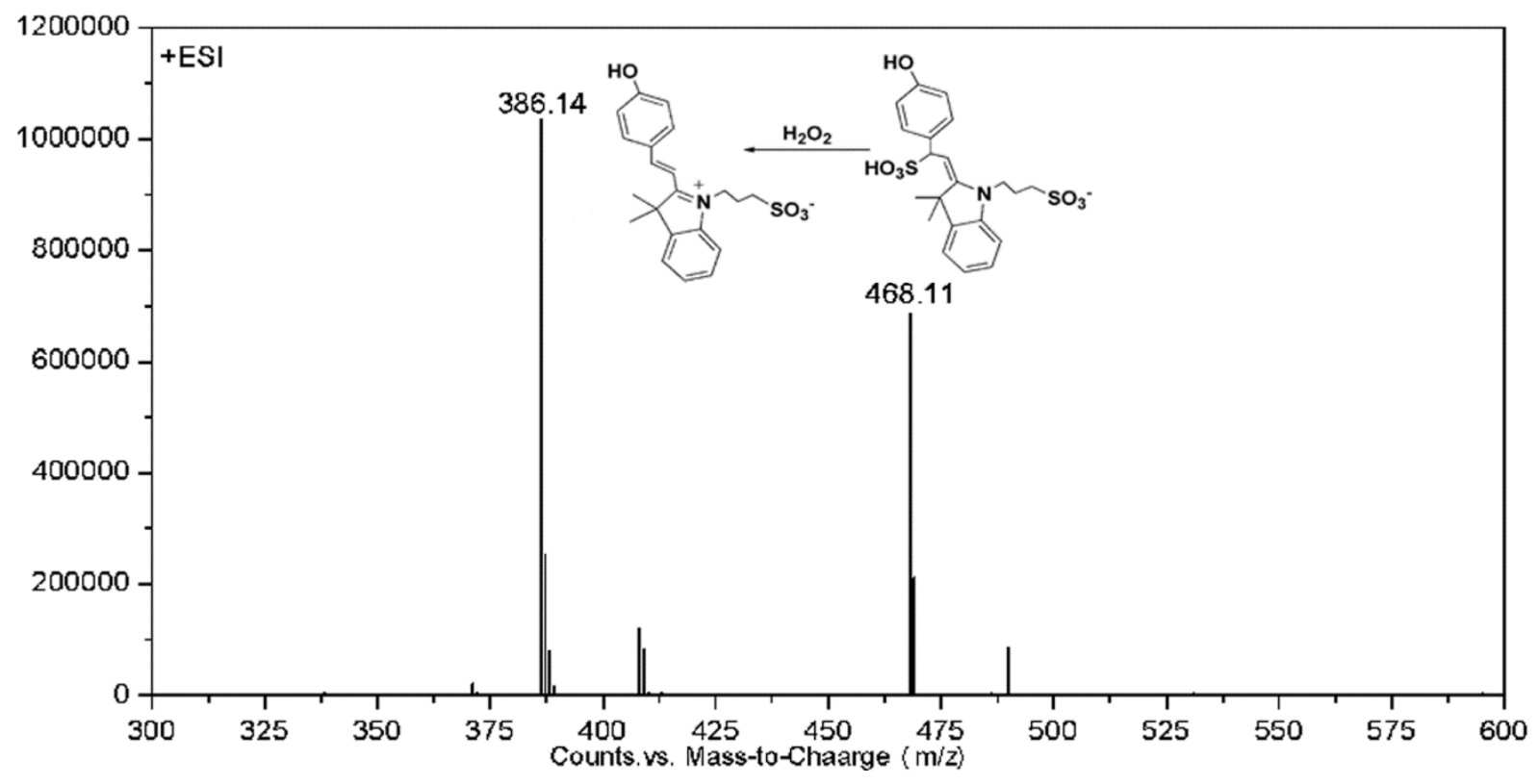

Figure S8. ESI-MS spectra of the reaction solution of $\mathrm{Cy}-\mathrm{OH}$ plus $\mathrm{HSO}_{3}{ }^{-}, \mathrm{H}_{2} \mathrm{O}_{2}$ in order.

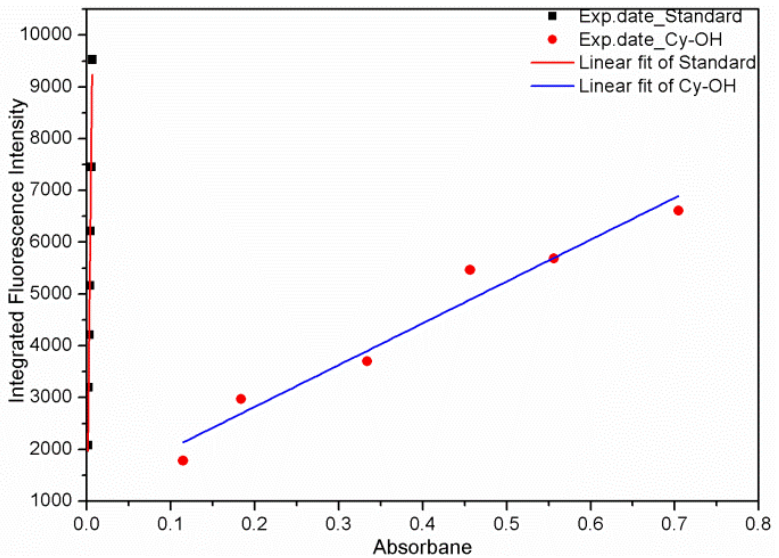

Figure S9. Determination of the fluorescence quantum yield of $\mathrm{Cy}-\mathrm{OH}$ based on Rhodamine B in ethyl alcohol solution as standard.

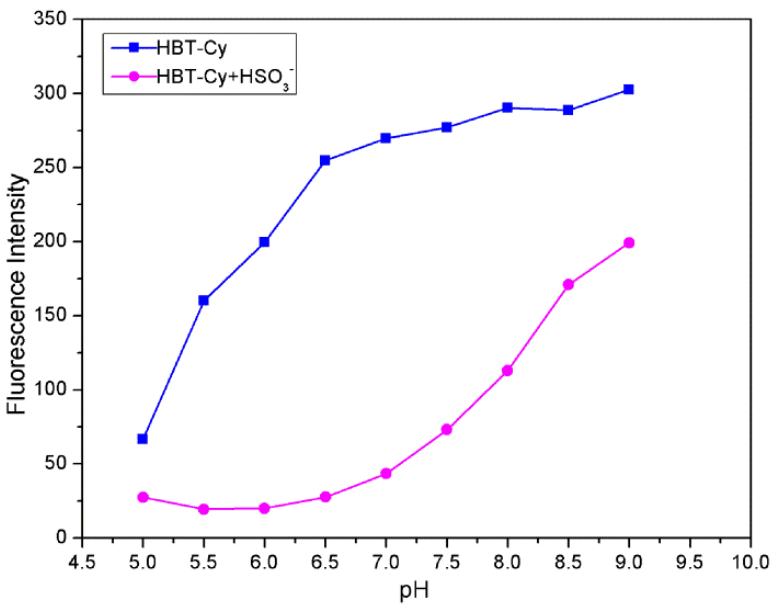

Figure S10. $\mathrm{pH}$ dependence of fluorescence intensity of probe HBT-Cy $(10 \mu \mathrm{M})$ in the absence and presence of $\mathrm{HSO}_{3}{ }^{-}(100 \mu \mathrm{M})$ in PBS solution $(50 \mathrm{mM})$. Both studies were performed at room temperature. $\lambda_{\mathrm{ex}}=520 \mathrm{~nm}, \lambda_{\mathrm{em}}=590 \mathrm{~nm}$, Each spectrum was recorded after $10 \mathrm{~min}$. 


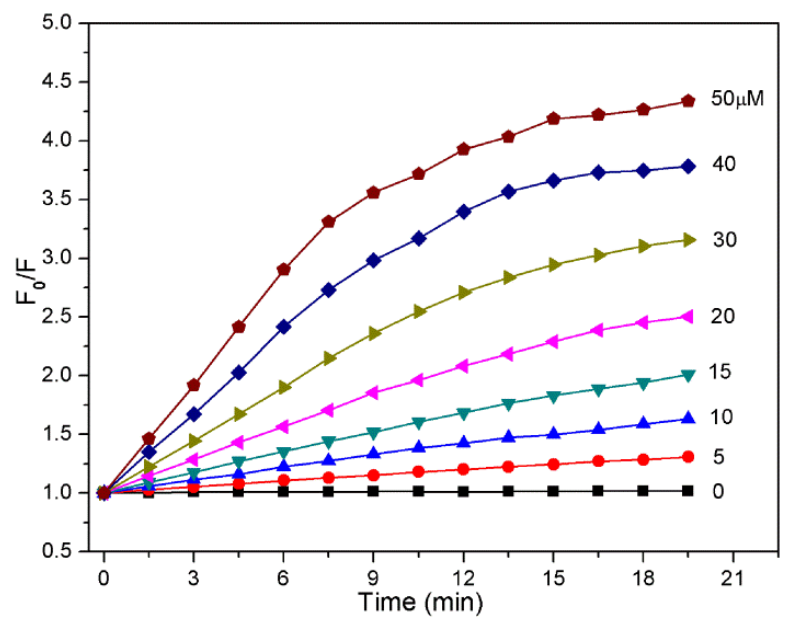

Figure S11. Time courses of the responses between HBT-Cy $(10 \mu \mathrm{M})$ with $\mathrm{HSO}_{3}{ }^{-}$at different concentrations in $50 \mathrm{mM}$ PBS solution (pH 7.0), $\lambda_{\mathrm{ex}}=520 \mathrm{~nm}, \lambda_{\mathrm{em}}=590 \mathrm{~nm}$.

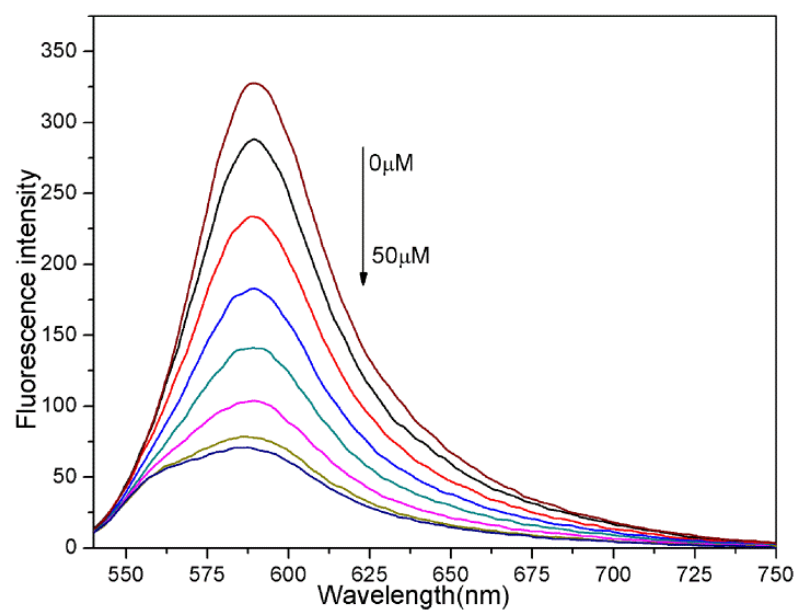

Figure S12. Fluorescence spectra of HBT-Cy $\left(10 \mu \mathrm{M}, \lambda_{\text {ex }}=520 \mathrm{~nm}\right)$ in the presence of different concentrations of $\mathrm{HSO}_{3}{ }^{-}(0,5,10$, $15,20,30,40,50 \mu \mathrm{M})$ in PBS 7.0 solution. Each measurement was performed after 15 min of mixing.

\section{Limit of Detection}

The limit of detection was determined with the equation: detection limit $=3 \sigma_{\mathrm{bi}} / \mathrm{m}$, where $\sigma_{\mathrm{bi}}$ is the standard deviation of blank measurements, $\mathrm{m}$ is the slope between intensity versus sample concentration. The fluorescence ratio $\left(\mathrm{F}_{450} / \mathrm{F}_{590}\right)$ were linearly proportional to the amounts of $\mathrm{HSO}_{3}{ }^{-}(0-50 \mu \mathrm{M})$ with a detection limit $(\mathrm{S} / \mathrm{N}=3)$ of $0.338 \mu \mathrm{M}$ in $\mathrm{PBS} 7.0$ solution $(50 \mathrm{mM})$, indicating that the probe $\mathrm{HBT}-\mathrm{Cy}$ is potentially useful for the quantitative determination of $\mathrm{HSO}_{3}{ }^{-}$concentrations in a large dynamic range. 


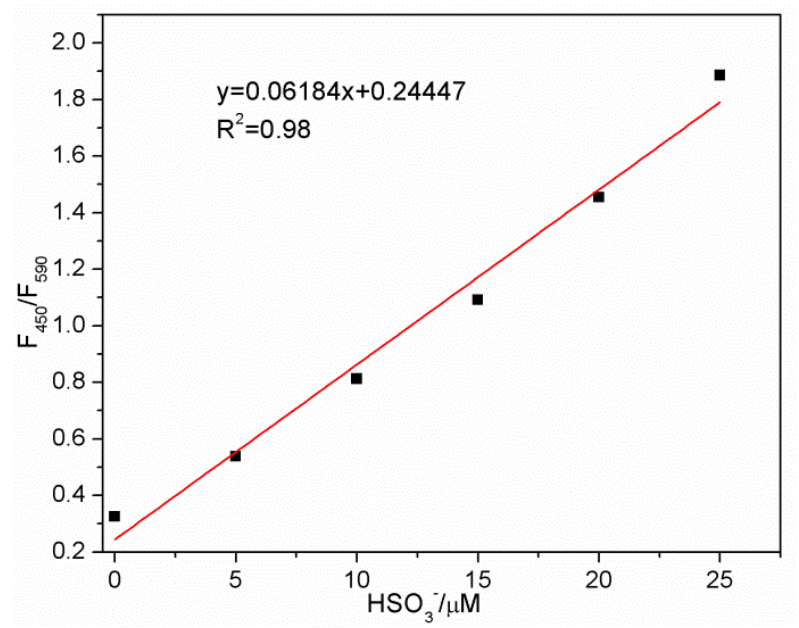

Figure S13. Ratiometric calibration curve of $\mathrm{F}_{450} / \mathrm{F}_{590}$ as a function of $\mathrm{HSO}_{3}{ }^{-}$concentration. Each measurement was performed after 15 min of mixing.

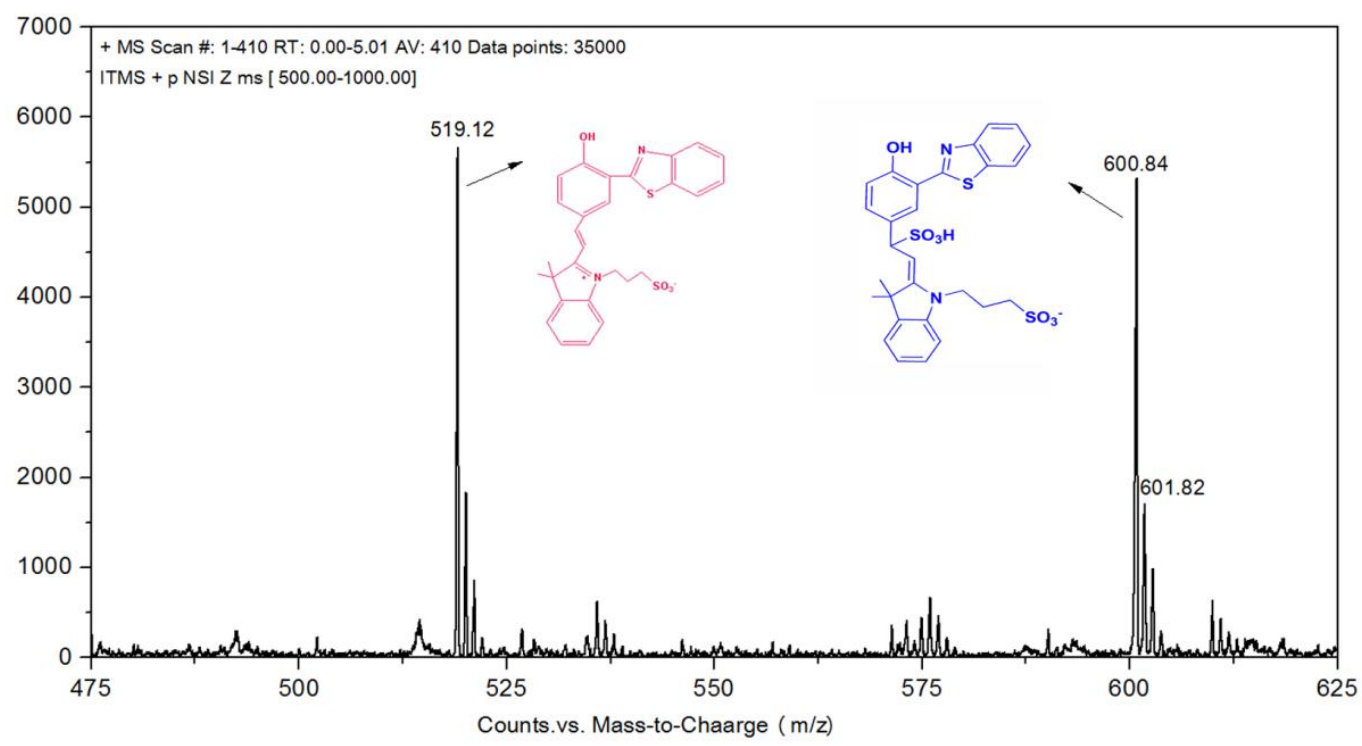

Figure S14. ESI-MS spectra of the reaction solution of HBT-Cy plus $\mathrm{HSO}_{3}{ }^{-}$.

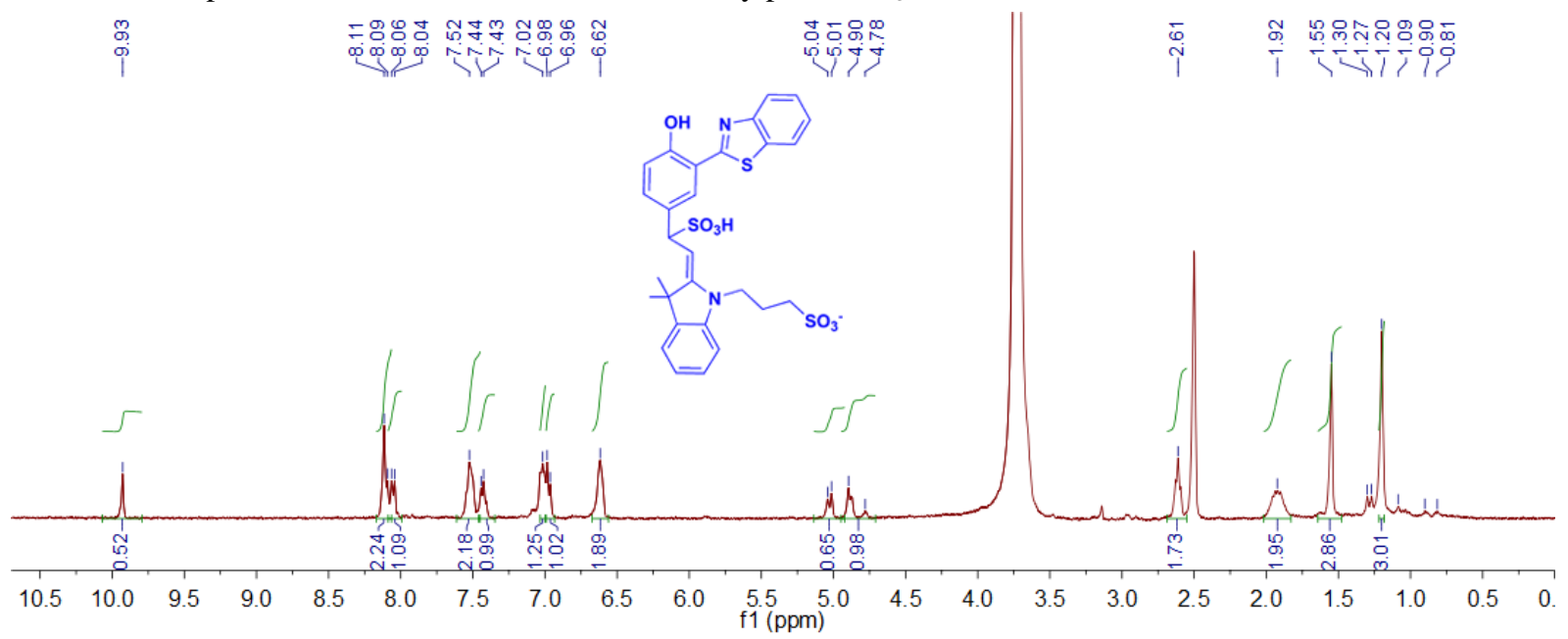

Figure S15. ${ }^{1} \mathrm{H}$ NMR spectrum of the fluorescence product HBT-CyO in DMSO $/ \mathrm{D}_{2} \mathrm{O}=8: 1(\mathrm{v} / \mathrm{v}) .{ }^{1} \mathrm{H}$ NMR $\left(400 \mathrm{MHz}, \mathrm{DMSO}-\mathrm{d}_{6}\right) \delta$ $9.95(\mathrm{~s}, 1 \mathrm{H}), 8.12(\mathrm{~d}, J=8.6 \mathrm{~Hz}, 2 \mathrm{H}), 8.07(\mathrm{~d}, J=8.5 \mathrm{~Hz}, 1 \mathrm{H}), 7.54(\mathrm{~s}, 2 \mathrm{H}), 7.45(\mathrm{~d}, J=7.0 \mathrm{~Hz}, 1 \mathrm{H}), 7.03(\mathrm{~s}, 1 \mathrm{H}), 6.99(\mathrm{~d}, J=8.7$ $\mathrm{Hz}, 1 \mathrm{H}), 6.64(\mathrm{~s}, 2 \mathrm{H}), 5.05(\mathrm{~d}, J=11.0 \mathrm{~Hz}, 1 \mathrm{H}), 4.86(\mathrm{~d}, J=46.2 \mathrm{~Hz}, 1 \mathrm{H}), 2.63(\mathrm{~s}, 2 \mathrm{H}), 1.94(\mathrm{~s}, 2 \mathrm{H}), 1.57$ (s, 3H), $1.22(\mathrm{~s}, 3 \mathrm{H})$. 


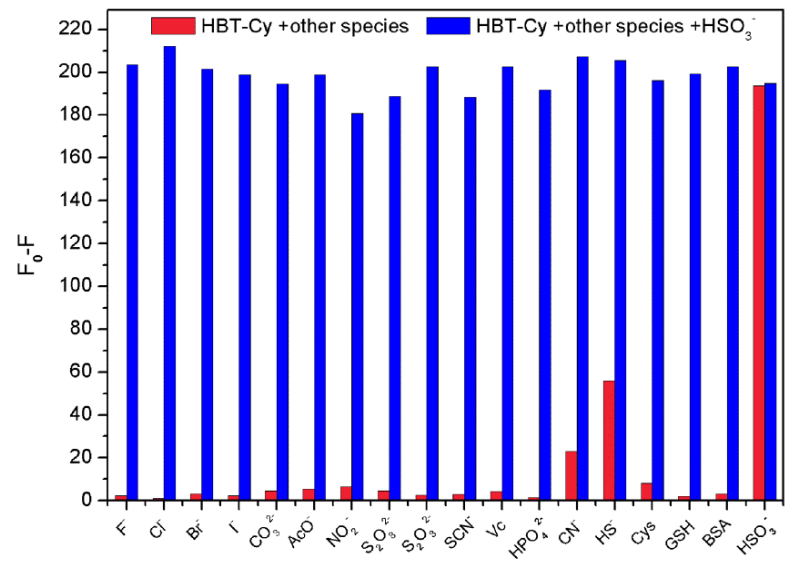

Figure S16. Selectivity and interference of $\mathrm{HBT}-\mathrm{Cy}$ towards $\mathrm{HSO}_{3}{ }^{-}$in the presence of other common species in $\mathrm{PBS} 7.0$ solution. The concentrations of $\mathrm{HSO}_{3}{ }^{-}$and other species were $50 \mu \mathrm{M}$ and $500 \mu \mathrm{M}$, respectively. $\mathrm{F}$ and $\mathrm{F}_{0}$ are the fluorescence intensity of HBT-Cy with and without other species at $590 \mathrm{~nm}$, respectively. Each measurement was performed after $15 \mathrm{~min}\left(\lambda_{\mathrm{ex}}=520 \mathrm{~nm}\right)$.

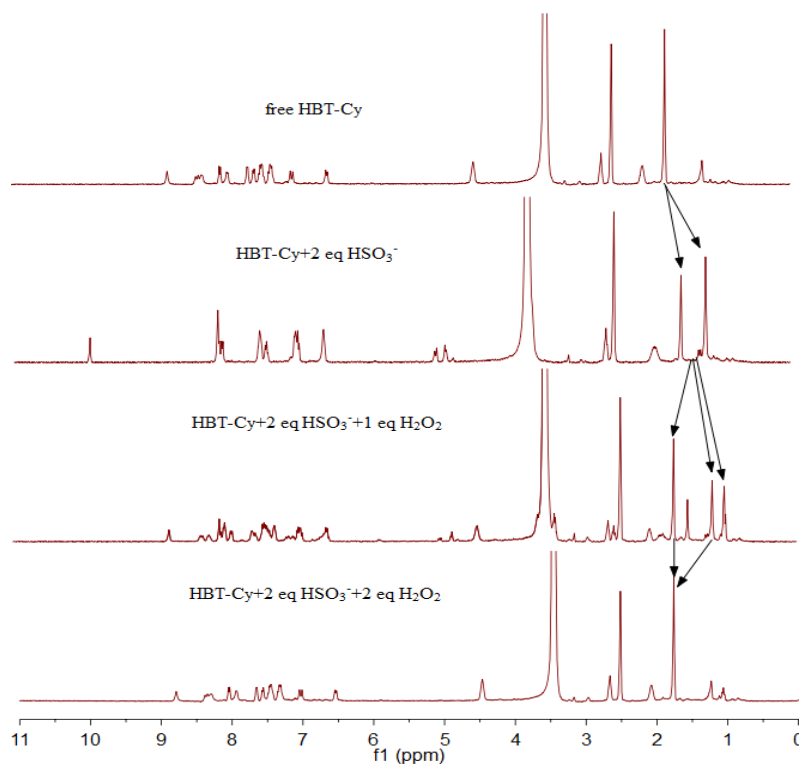

Figure S17. ${ }^{1} \mathrm{H}$ NMR titration spectra of HBT-Cy in DMSO- $\mathrm{d}_{6}$ upon addition of $\mathrm{HSO}_{3}{ }^{-}$in $\mathrm{D}_{2} \mathrm{O}$ and subsequent addition of $\mathrm{H}_{2} \mathrm{O}_{2}$ $\left(\mathrm{D}_{2} \mathrm{O}\right)$. 


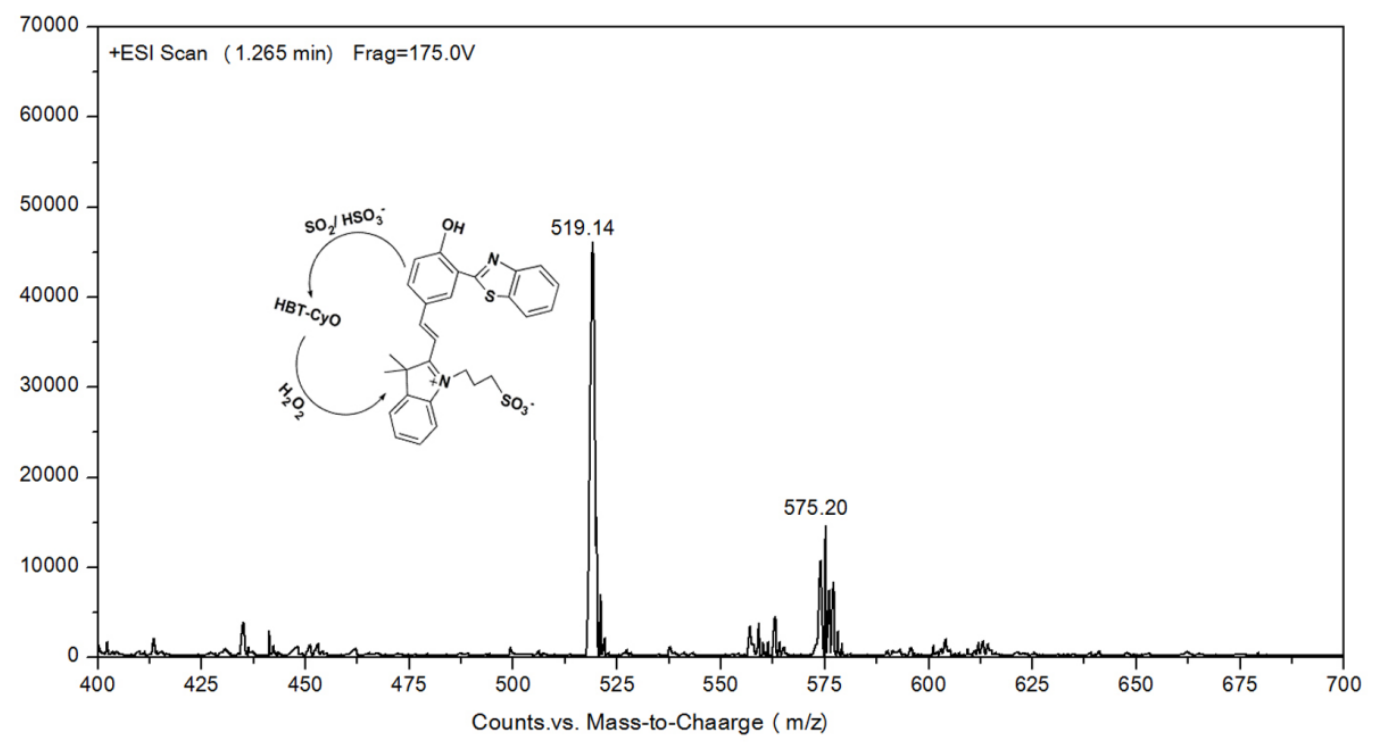

Figure S18. ESI-MS spectra of the reaction solution of HBT-Cy plus $\mathrm{HSO}_{3}{ }^{-}, \mathrm{H}_{2} \mathrm{O}_{2}$ in order, which is identical to that of the primary compound, seen Figure S2

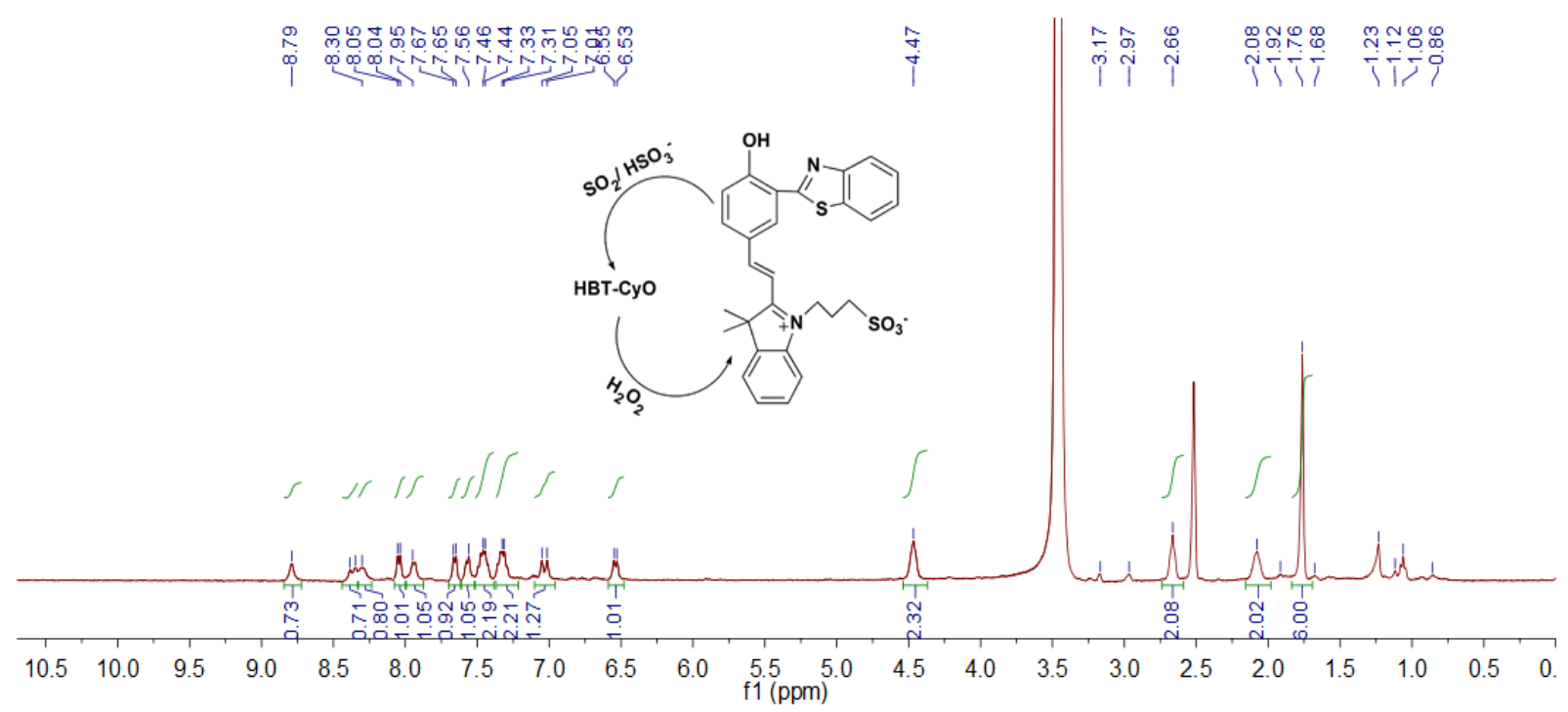

Figure S19. ${ }^{1} \mathrm{H}$ NMR spectrum of the restored probe HBT-Cy in DMSO/D $2 \mathrm{O}=8: 1(\mathrm{v} / \mathrm{v}) .{ }^{1} \mathrm{H}$ NMR $\left(400 \mathrm{MHz}, \mathrm{DMSO}-\mathrm{d}_{6}\right) \delta 8.79(\mathrm{~s}$, $1 \mathrm{H}), 8.37(\mathrm{~d}, J=14.6 \mathrm{~Hz}, 1 \mathrm{H}), 8.30(\mathrm{~s}, 1 \mathrm{H}), 8.04(\mathrm{~d}, J=7.5 \mathrm{~Hz}, 1 \mathrm{H}), 7.95(\mathrm{~s}, 1 \mathrm{H}), 7.66(\mathrm{~d}, J=7.3 \mathrm{~Hz}, 1 \mathrm{H}), 7.56(\mathrm{~s}, 1 \mathrm{H}), 7.45(\mathrm{~d}, J$ $=5.5 \mathrm{~Hz}, 2 \mathrm{H}), 7.32(\mathrm{~d}, J=5.9 \mathrm{~Hz}, 2 \mathrm{H}), 7.03(\mathrm{~d}, J=14.5 \mathrm{~Hz}, 1 \mathrm{H}), 6.54(\mathrm{~d}, J=7.9 \mathrm{~Hz}, 1 \mathrm{H}), 4.47(\mathrm{~s}, 2 \mathrm{H}), 2.66(\mathrm{~s}, 2 \mathrm{H}), 2.08(\mathrm{~s}, 2 \mathrm{H})$, $1.76(\mathrm{~s}, 6 \mathrm{H})$.

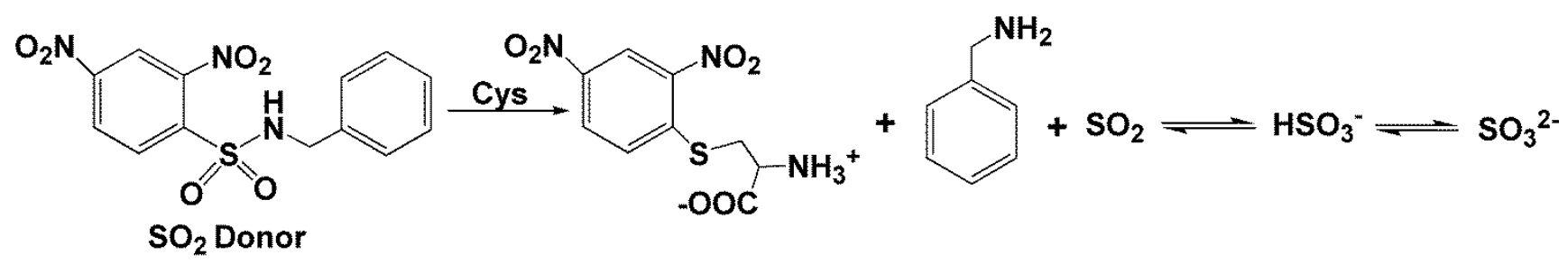

Figure S20. Reaction of $\mathrm{SO}_{2}$ donor in the presence of Cys. 


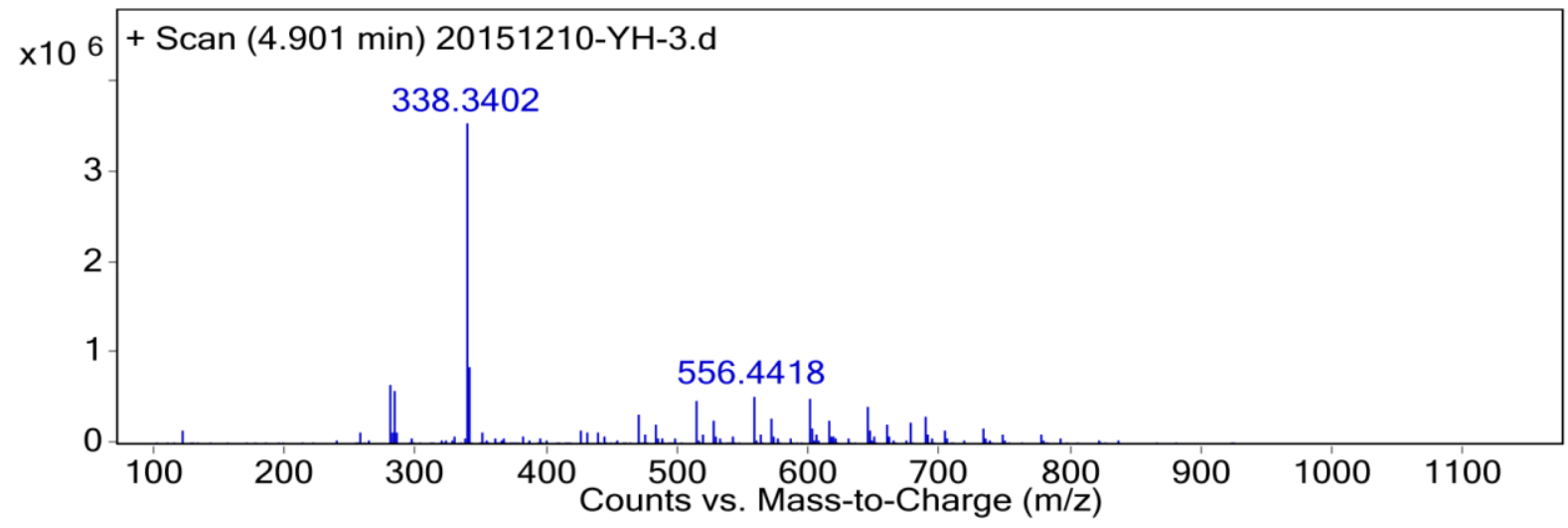

Figure S21. ESI-MS spectra of $\mathrm{SO}_{2}$ donor.
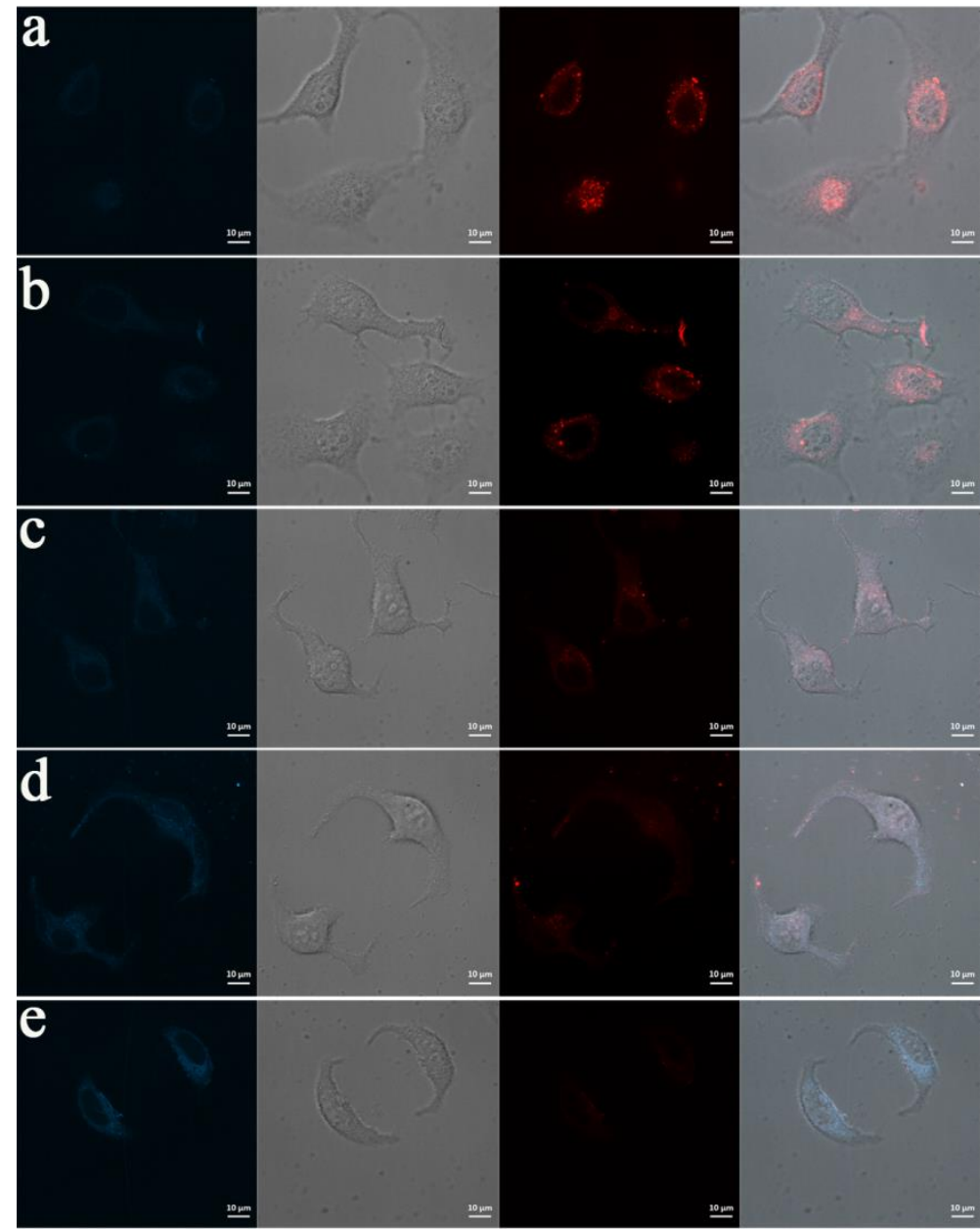

Figure S22. Confocal imaging of living MCF-7 cells incubated with different concentrations of NaHSO 3 (a: $0 \mu \mathrm{M}, \mathrm{b}: 5 \mu \mathrm{M}$, c: 10 $\mu \mathrm{M}$, d: $20 \mu \mathrm{M}$, e: $50 \mu \mathrm{M}$ ) in the blue channel, bright field, red channel and overlay field (left to right). Ex@405 nm for the blue channel (425-510 nm), Ex @520 nm for the red channel (560-650 nm). 


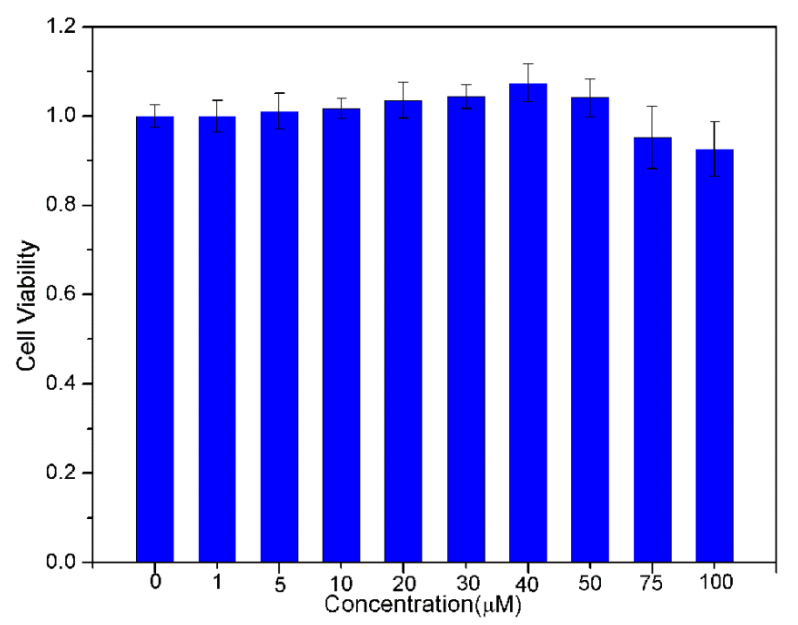

Figure S23. Cytotoxicity assay of probe HBT-Cy at different concentrations for MCF-7 cells after $24 \mathrm{~h}$.

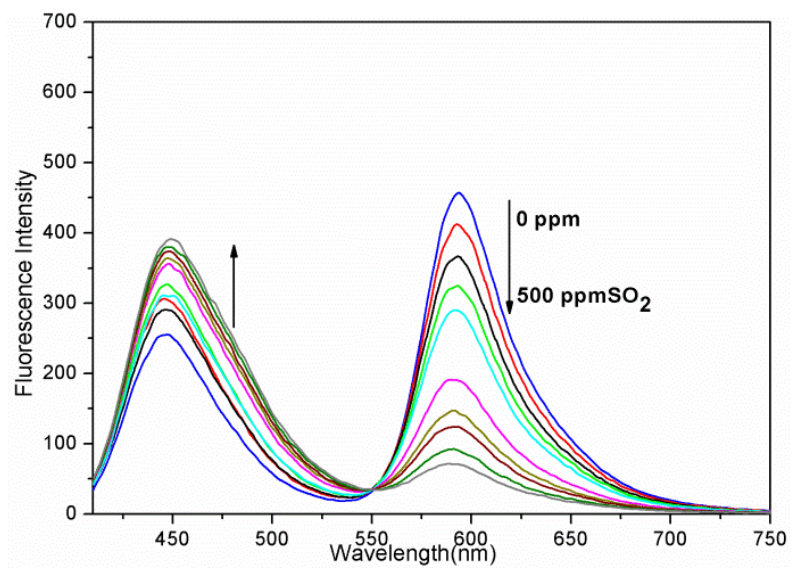

Figure S24. Ratiometric fluorescence spectra of HBT-Cy in PBS 7.0 solution $(20 \mu \mathrm{M})$ upon addition of $\mathrm{SO}_{2}$ gas $(0-500$ ppm). The fluorescence spectra were recorded with excitation at $390 \mathrm{~nm}$.

The fluorescence ratio $\left(\mathrm{F}_{450} / \mathrm{F}_{590}\right)$ were linearly proportional to the amounts of $\mathrm{SO}_{2}(0-400 \mathrm{ppm})$ with a detection limit(S/N=3) of $0.659 \mathrm{ppm}$ in PBS7.0 solution $(50 \mathrm{mM})$, indicating that the probe HBT-Cy is potentially useful for the quantitative determination of $\mathrm{SO}_{2}$ concentrations.

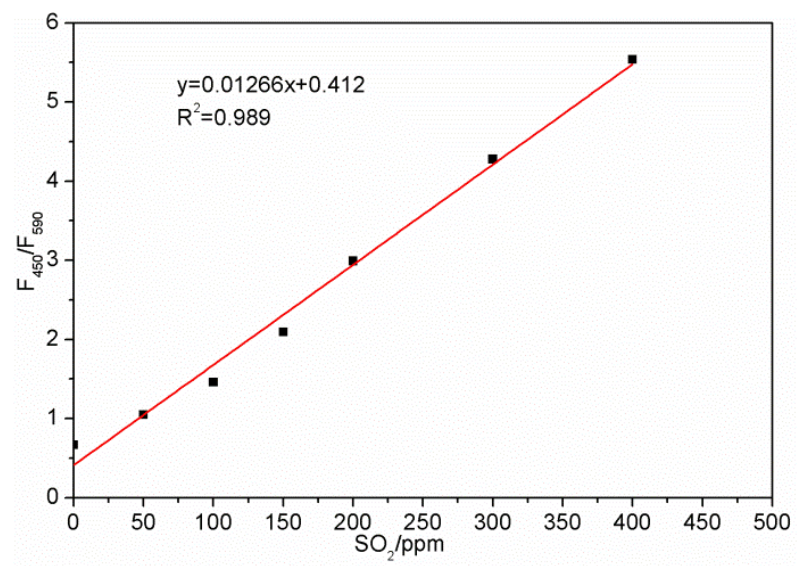

Figure S25. Plot of the fluorescence intensity ratio $\left(\mathrm{F}_{450} / \mathrm{F}_{590}\right)$ for HBT-Cy $(20 \mu \mathrm{M})$ vs the concentration of $\mathrm{SO}_{2}$ gas. Each data was acquired 15 min after $\mathrm{SO}_{2}$ addition in PBS 7.0 solution. 
Table S1. Recovery test of $\mathrm{HSO}_{3}{ }^{-}$spiked in tap water, lake water and rain water.

\begin{tabular}{|c|c|c|c|c|c|c|c|c|c|}
\hline \multirow{3}{*}{$\begin{array}{l}\text { Spiked } \\
\mathrm{HSO}_{3}^{-} \\
(\mu \mathrm{M})\end{array}$} & \multicolumn{3}{|c|}{ Tap water } & \multicolumn{3}{|c|}{ Lake water } & \multicolumn{3}{|c|}{ Rain water } \\
\hline & \multicolumn{3}{|c|}{ Found $(\mu \mathrm{M})$} & \multicolumn{3}{|c|}{ Found $(\mu \mathrm{M})$} & \multicolumn{3}{|c|}{ Found $(\mu \mathrm{M})$} \\
\hline & \multicolumn{3}{|c|}{ Recovery (\%) RSD (\%) } & \multicolumn{3}{|c|}{ Recovery (\%) RSD (\%) } & \multicolumn{3}{|c|}{ Recovery (\%) RSD (\%) } \\
\hline 15 & 17.4 & 116.2 & 2.9 & 18.8 & 125.1 & 4.5 & 17.1 & 114.3 & 1.1 \\
\hline 30 & 27.2 & 90.7 & 2.8 & 34.6 & 115.3 & 0.9 & 29.2 & 97.3 & 1.7 \\
\hline 45 & 43.2 & 95.9 & 2.1 & 46.5 & 103.2 & 7.0 & 44.5 & 98.9 & 6.3 \\
\hline
\end{tabular}

\section{Reference}

(S1) Mason, S. J.; Hake, J. L.; Nairne, J.; Cummins, W. J.; Balasubramanian, S. J. Org. Chem., 2005, 70, $2939-2949$.

(S2) Lapteva, A. V.; Belikov, N. E.; Lukin, A. Y.; Strokach, Y. P.; Barachevsky, V. A.; Alfimovb, M. V.; Demina, O. V.; Shvets, V. I.; Skladnev, D. A.; Khodonov, A. A. Russ. J. Bioorg. Chem. 2008, 34, 252-260.

(S3) Keengo, S.; Atsushi, K.; Shigeo, K.; Kazuyuki, T.; Toshitada, Y.; Hitoshi, I.; Yoshimi, S.; Shigero, O.; Seiji, T. Phys. Chem. Chem. Phys. 2009, 11, 9850-9860.

(S4) Malwal, S. R.; Sriram, D.; Yogeeswari, P.; Konkimalla, V. B.; Chakrapani, H. J. Med. Chem., 2012, 55, 553-557. 